\title{
The Myanmar Peace Center: Its Origins, Activities, and Aspirations
}

\author{
N. Ganesan
}

\section{Introduction}

The Myanmar Peace Center (MPC) is one of the newest organizations with a focus on peace in Asia. It was initially formed in October 2012 with a core group of 13 members. Since then it has gone on to become a much larger and also much more institutionalized organization. The nature of its work differs from that of most other peace research centers in that it is the organization appointed by the Myanmar President and government to bring an end to ethnic and sectarian conflict in the country. The MPC, unlike other organizations, is actively involved in negotiating peace with the country's major ethnic insurgent groups, many of which have been fighting the government for almost six decades now.

This article traces the origins of the MPC and its mandate within the Myanmar government's ongoing attempts to sign a nation-wide ceasefire deal to bring closure to the long history of ethnic conflict that has plagued the country. It also identifies the organizational structure of the MPC and the key personnel involved in the ongoing negotiation efforts. The MPC faces a number of obstacles to its ongoing work and these are examined as well, together with a projection of how the institution will evolve as the country heads towards the next parliamentary elections in 2015.

\section{Background: Political Dynamics}

This section provides an abbreviated political history of Myanmar and places the country's ethnic armed groups in contextual perspective. It also looks at the political changes that have occurred since the country's election in November 2010 and the place of the MPC within this broader landscape. (For a more 
complete sketch of the historical background, see the author's article published in the immediate previous issue of the Asian Journal of Peacebuilding.) (Ganesan 2013)

At the time of independence from Great Britain in 1948, Myanmar (called Burma until 1989) confronted a number of immediate political problems. One of the most significant of these was the country's heterogeneous ethno-linguistic population. Structurally, the British had failed to meaningfully unite the highland areas that were dominated by the ethnic minorities and the lowland areas that they controlled. This failure meant that there was precious little by way of historical precedent to weld the country together. Consequently, the domestic political situation deteriorated rapidly and many of the ethnic minority groups took up arms against the government. Of the approximately 26 ethnic insurgent armies that fought the government in the post-independence period, the largest were those that represented the Karen, Kachin, and Shan ethnic groups (Smith 1991; 1999).

Ethnicity and religion became major contentious issues that threatened to divide the country in the post-independence period. Following military coups in 1959 and 1962, the military strongman Ne Win headed the country and rule was exercised through the Burma Socialist Programme Party (BSPP) that served as a vehicle for the military. Later military strongmen would emulate this strategy of creating a peak mass based political party and inaugurate the Union Solidarity and Development Association (USDA). The government introduced a form of radical socialism, nationalized the economy, and practiced a foreign policy of neutrality obtained through isolationism resulting in a serious deterioration of the country's economy and infrastructural capacity (Ganesan 2005, 32; 2010, 4-5; Haacke 2006, 10; Steinberg 2001; Taylor 2009, 355-356).

The collapse of the BSPP government in 1988 occurred at a time when there was a confluence of important developments that resulted in a significant conjuncture and led in turn to the military's initial agreement to democratic reforms and nationwide elections in 1990. The National League for Democracy (NLD), led by Aung San Suu Kyi (who had returned to the country in 1988), won a landslide victory in the elections, but the outcome was subsequently ignored by the military government, and from 1990 onwards Suu Kyi was periodically detained while her political vehicle, the NLD, was heavily scrutinized and harassed.

In order to stabilize the domestic political situation the military junta signed ceasefire agreements with some 20 ethnic insurgent groups that were allowed to retain control of designated contiguous territories while retaining their weapons (Smith 1991; 1999; Steinberg 2006). ${ }^{1}$ Simultaneously, the government mounted major military offensives against groups that did not accede to similar arrangements. The military government also undertook a series of structural reforms. The government convened a National Convention, first announced in 
1993, to write a new Constitution. This process was part of a seven-point "roadmap to democracy" introduced in 2003 (Holliday 2011, 82). The Constitution that was subsequently drafted and announced in May 2008 was eventually ratified through a public referendum shortly afterwards (Taylor 2009, 487). Many of the ethnic insurgent groups and the NLD opted out of this National Convention and there were widespread allegations of fraud during the referendum that was held to ratify it. The 2010 elections were then held based on the 2008 Constitution and the government's mass-based party, the Union Solidarity and Development Party (USDP), won a landslide victory. The NLD's obvious reason for refusing to participate in the elections was the fear of relinquishing its previous victory in 1990. Besides, its leader Suu Kyi was under house arrest when the elections were called in November 2010.

The elected government of 2010 is predominantly led by senior military officers. The SPDC's most senior officers, Generals Than Shwe and Maung Aye, retired from politics and turned over power to Thein Sein, who now serves as President of the country, together with many colleagues also drawn from the military. In August 2011 Thein Sein made a conciliatory gesture to Suu Kyi by inviting her for a meeting at the new capital city of Naypyitaw. The NLD was then allowed to register as a political party in order to compete in the April 2012 byelections where it won 43 out of 45 seats. ${ }^{2}$ This development in turn led to Suu Kyi becoming a Member of Parliament and on the basis of her overwhelming victory at the polls, she also serves as the unofficial leader of the opposition. The ethnic political parties represented in Parliament often work in collaboration with the NLD as well. Even the ethnic ceasefire groups have called for the inclusion of the NLD in their political dialogues with the government.

A number of other political decisions undertaken by the Thein Sein government has led to the gradual evolution of a seemingly more liberal domestic political environment. Prior to the April 2012 by-elections, the government freed a large number of political detainees. The freeing of political prisoners widened political space and was also welcomed by many Western countries which subsequently lifted the sanctions regime or loosened it considerably (ChannelnewsAsia 2013). Apart from freeing political prisoners, the government decided to grant a broad-based amnesty to political exiles living abroad. There were a large number of such exiles living in India, Thailand, and the West that had previously provided information and organized anti-government activities. The government also went out of its way to accommodate leading members of the 88 Generation group that was involved in leading anti-government demonstrations as well. It has also inducted many returned exiles into the newly created Myanmar Peace Center. 


\section{The History, Organizational Structure, and Mandate of the MPC}

The MPC was inaugurated in October 2012 in Yangon and currently serves as the government's vehicle for negotiating meetings with the ethnic armed groups in order to achieve long-term accommodation and peace. The MPC owes its origins to the initiatives of leading members of another organization, Myanmar Egress (ME). In fact, Myanmar Egress was the organization that was deeply involved in initiating the process of political change and accommodation. It was formed in 2006 by a group of six locals who wanted to do something about the country's political situation. ${ }^{3}$ Consequently, and through some of their contacts in the military as well as the publications associated with the group, ME was able to achieve what no other local NGO could. It was able to establish lines of communication with the military government and persuade it to engage in dialogue with the different stakeholders in the country, including the armed insurgent groups. The core group within ME benefitted immensely from their diverse linkages inside and outside the country and with the locally based foreign diplomatic community as well. The early peace negotiations with the armed groups were done on an ad hoc basis at the outset and the institutionalized process only came much later. The push to create the MPC was spearheaded by Tin Maung Than and Sonny Nyunt Thein, ME's President and External Vice President respectively.

ME gained exceptional publicity for its work in the aftermath of cyclone Nargis in 2008. Owing to the large number of classes in social entrepreneurship that it conducted from its early premises at the Tamada Hotel in Yangon, it was able to draw on a large alumni network to assist in recovery and developmental work in the delta areas that were ravaged by the cyclone. It was ME that facilitated the entry of aid organizations like the UN agencies and ASEAN to assist in the relief efforts. In 2008 the military government led by General Than Shwe was still deeply suspicious of foreigners and their involvement in domestic developments. Not only did ME manage to strengthen itself, but importantly, it provided the wherewithal and support for another NGO that was much more focused on relief and developmental work-Network Activities Group (NAG). The immense outpouring of grief and international goodwill also meant that both ME and NAG grew at a pace disproportionate to any of the other NGOs. Both groups drew on funds from many international donors from Australia, the European Union, Germany, Sweden, the United Kingdom, and the UN.

President Thein Sein was one of the early architects and supporters of the process to engage the ethnic insurgent groups in the peace process. Following on from the early ceasefire agreements that had been negotiated by General Khin Nyunt (removed as Prime Minister and head of Military Intelligence in October 2004), two peace committees were formed. The first of these comprising 
seven to eight persons was the Union Peace-making Central Committee that was located in Naypyitaw and chaired by the President himself. The second and larger Union Peace-making Work Committee comprising some 50 persons is chaired by Vice President Dr. Sai Mauk Kham. Both of these early committees and the process of peace negotiations required a central secretariat from which to operate. And this central clearing house was the MPC. Much of the progress and institutionalization of the MPC occurred only in the aftermath of the 2010 elections.

In late October 2012, President Thein Sein issued an Executive Order naming 13 individuals as executive members of the MPC's Board of Management. The Board, which is drawn from the different ministries, the President's Office, and the military, is chaired by the government's chief ceasefire negotiator, $U$ Aung Min. Prior to his current appointment, he served as Minister for Railways Transportation. In 2012, in order to take up the new appointment, he was seconded as Minister in the Office of the President in Naypyitaw. In addition to these appointees, there are four special advisers to the MPC: Tin Maung Than and Hla Maung Shwe from Myanmar Egress, Yin Yin Nwe (a former United Nations appointee), and Thant Myint U, whose grandfather was former UN Secretary General U Thant.

Then there is a separate group of individuals who are involved in the peace negotiation process as well. Many of these individuals are drawn for their linkages with ethnic armed groups and some of them are returned political exiles. This group includes Aung Nain Oo, who was previously with the Vahu Development Institute in Chiangmai, Min Zaw Oo from the All Burma Students' Democratic Front (ABSDF), Nyo Ohn Myint from the NLD-Liberated Areas, Dr. Andrew Ngun from the Chin National Front (CNF), and Dr. Kyaw Yin Hlaing, an academic who relinquished his appointment at the City University of Hong Kong to become involved in the country's political reconstruction. Kyaw is also a founding member and board member of Myanmar Egress.

Apart from the aforementioned appointment holders, the MPC has a total of 75 administrative support staff and that number is expected to increase to a full complement of 150 when the ongoing work and staff recruitment is fully completed and all the related programs are set up and running. Unlike the mostly ad hoc early ceasefire arrangements that were meant to bring political calm to the country during a time of political transition, the work of the MPC is designed to be much more structured and long lasting. The current terms and conditions include deep engagement in the process of political dialogue with the insurgent groups as well as peace-building activities to consolidate the ongoing efforts.

The MPC, which serves as the coordinating secretariat for the Union Peacemaking Work Committee, is physically located in 11 Shweli Road in Kamaryut Township in Yangon. The government donated four detached bungalows in kind and had these renovated and additional buildings added in order to 
facilitate meetings with the different groups and consolidate itself structurally and administratively. The European Union provided an initial grant of 700,000 Euros in 2012 and has promised a total of US $\$ 30$ million spread over five years. However, much of this grant will only become available after the ceasefire agreements have been signed and as part of the real peace process. The Japanese government, through its Embassy in Yangon, also donated US\$1.2 million in March 2013 with additional support for offices, meeting spaces, furniture, and electrical supplies. This gift was part of the Japanese government's Grant Assistance for Grassroots Human Security Projects Scheme.

The MPC's most significant and important mandate is the conclusion of a nationwide ceasefire deal with all the ethnic insurgent armies. The government has been quite successful in this regard by bringing into the fold the three last such groups to sign ceasefires in 2012. These were the Chin National Front (CNF), the Karen National Union (KNU), and the Kayinni National Progressive Party (KNPP). On the other hand, however, it has suffered a setback with the breakdown of the ceasefire agreement since June 2011 with the Kachin Independence Organization (KIO) and its armed wing, the Kachin Independence Army (KIA). As a result of the resumption of fighting between the military and the KIA in Kachin state, there are now approximately 140,000 internally displaced persons (IDPs) within the state. Of these some 90,000 are in government held areas while the remainder are in areas controlled by the KIA. The most recent skirmish occurred in April 2014 and casualties have been reported on both sides, which suggests that, notwithstanding the ongoing dialogue between the KIO and the government, sporadic fighting continues (Eleven Newsmedia 2014g). Whereas the government accused the KIA of a preemptive attack on its troops and involvement in the illegal felling and sale of timber to China, the KIA accused the government of attempting to enlarge control of areas outside its jurisdiction (Eleven Newsmedia 2014h). It also accuses the government of attempting to control supply routes in order to choke off the KIA stronghold and headquarters at Laiza. In the meantime, the government has allowed international access to the IDPs for aid and relief work. Apart from this major breakdown, there are occasional skirmishes in the Shan states involving the Revolutionary Council of the Shan States (RCSS) that was previously referred to as the Shan State ArmySouth (SSA-S).

The MPC and Thein Sein government's approach to the ceasefire negotiations is to consolidate the ongoing process at three levels. In the first instance, the ceasefire will be negotiated at the regional level. Subsequently, the agreement will be endorsed at the state level, in accordance with the geographical and administrative division of the country. Finally, all the ceasefire groups will convene a meeting with the government where a nationwide ceasefire agreement will be signed. The last stage of the agreement is meant to replicate the historical Panglong Agreement that was signed by General Aung San in 1947 with the 
ethnic groups. The intention of the current government is to conclude the final stage of the agreement by 2014 in order to avoid the politically charged atmosphere of 2015 when the country will hold nationwide elections. Yet, this signing ceremony has proved to be elusive. There were originally plans for the document to be signed in January 2014, but it has been postponed a number of times and the hope now is that it will be signed at the very latest by August 2014. Some of the difficulties associated with the signing of this document will be discussed in the next section.

At a later stage and after the nationwide ceasefire agreement has been signed, the MPC will also become involved in the peace monitoring process. The current terms of reference also include the MPC's involvement in political dialogue with the insurgent groups to resolve outstanding issues. The next stage of the process will then be peacebuilding. At this stage the MPC is expected to interact and liaise with foreign donors. It will also serve as the central agency and clearing house for the facilitation of interactions between the local and international implementing agencies.

The MPC will in the future launch a Public Outreach Programme. As part of this initiative, an Office of Public Diplomacy will be set up. The aim of this office is to serve as the nodal point for the dissemination of information about the activities and targets of the MPC. A corollary of this office will be the Mine Action Center. This Center will become operational after broad-based agreement has been reached with the ethnic insurgent groups to significantly deescalate the conflict. Finally, the MPC also intends to become involved in ongoing disputes over land ownership through the creation of a Land Center. There have been numerous complaints about farmland being illegally seized without proper compensation and the Parliament and political parties have agreed to look into such cases. Equally, there have been quite a few instances of squatter settlements that have been evicted and large numbers of homeless persons created as a result. Over time this effort is likely to become a time consuming process as well since it will involve scrutinizing relevant documents and then perhaps arbitration of disputes or their referral to the legal system for adjudication.

\section{MPC's Achievements and Setbacks}

The MPC, for the relatively short time that it has been in existence, has indeed achieved much. It has managed to bring almost all of the ethnic armed groups into ceasefire agreements and, for the most part, active fighting has indeed stopped. Lead negotiators of the MPC have been able to establish a good measure of trust in order to serve as reliable and relatively neutral intermediaries. In fact, one of the more positive outcomes of the ongoing negotiations is that the armed groups trust the government's lead negotiator, U Aung Min, and are anxious to 
conclude important deals while he leads the negotiating team. In this regard the MPC has achieved a good measure of institutionalization and recognition for its efforts. Such recognition is also forthcoming from the international community which has actively encouraged the MPC and provided funding to see the process through.

Notwithstanding these impressive achievements within a short period of time, there are difficulties that the MPC has encountered as well. Perhaps the most jarring difficulty has been in successfully concluding the ceasefire negotiations within the time limit that the government had originally set. The signing of the nationwide ceasefire deal has been postponed many times up to now, although there is hope that it will eventually be signed in 2014. Part of the reason for the delay is the drawn out nature of the negotiation process and the differences in the positions on both sides. Much more time was needed to achieve terms that were mutually acceptable to both parties. The government also appears to have hastily announced signing dates without taking into consideration the conditions on the ground or the protracted nature of the negotiations.

Whereas the general level of trust between the ceasefire groups and the government is quite high, groups like the All Burma Students' Democratic Front (ABSDF), Kachin Independence Organization (KIO), Revolutionary Council of the Shan States (RCSS), and the United Wa State Army (UWSA) have not always been agreeable or cooperative and sporadic fighting has broken out from time to time in Kachin and Shan states. The groups are also attempting to project a united front in order to have much stronger negotiating terms and positions. The latest development in this regard is the formation of the Nationwide Ceasefire Coordination Team (NCCT) that was formed in October 2013 after a meeting in Laiza (Eleven Newsmedia 2014d). The NCCT draws its membership and office bearers from the larger ceasefire groups and has recently been spearheading meetings with the MPC. Also, in February 2014, the ethnic groups launched the Pyidaungsu Institute (PI) in Chiang Mai, Thailand, to coordinate the position of the different ethnic groups. Office bearers of the PI are also drawn from the major ethnic groups and the stated policy position is to provide a common platform for dealings with the MPC (Eleven Newsmedia 2014b). Although the PI was quick to point out that it intends to work together with the MPC, the fact that it identified the MPC as a government initiative seems to suggest that it will seek to better represent the interests of the ethnic groups. Interestingly and in line with previous activities, the PI is headquartered in northern Thailand rather than in Myanmar and this fact itself may prove problematic for a government that is trying to resolve differences internally. The Myanmar government is also aware of the previous Thai policy of supporting some of the ethnic groups, including the KNU and the SSA-S, as part of a historical buffer policy (Chachavalpongpun 2005).

Myanmar as a country does not have a culture of peace, and almost six 
decades of ethnic insurgency has led to high levels of anxiety and distrust between the government and the ethnic groups. The generation of adequate trust to move the negotiations forward has taken a long time. The MPC has had to prove itself a worthy interlocutor to be taken seriously by the ethnic groups and the acquisition of a good reputation takes time. Myanmar as a country also does not have an established history of building strong institutions; policies were often delivered piecemeal in the past. Additionally, after six decades of independent administration of their own territories, there is a firmly established insurgent political economy and informal network of ties that is not easy to bypass or change. This situation is especially true for groups like the Kachin and $\mathrm{Pa}-\mathrm{O}$ that control areas with lucrative jade mines. In fact, recent fighting between the KIA and the army is believed to be centered on government attempts to halt the sale of illegally felled teakwood by the KIO to traders in China. Overcoming internal vested interests is a major problem, and the government has come to realize that unless socio-economic development is carried out in the areas controlled by ceasefire groups, the likelihood of an enduring settlement will remain elusive. So for instance, the government's early plan to convert the ethnic armies into part of a Border Guard Force (BGF) was swiftly rejected by the major groups like the Kachin, Karen, Shan, and Wa. These groups feared that acceptance of such an arrangement would effectively neutralize their fighting units without any tangible benefits to be had in the process. It would also have effectively deprived them of the ability to return to armed conflict should the negotiations collapse.

Although the MPC is the designated institution for dealing with the ethnic groups, it does not always have the full support of the government or other state agencies. So for example, the Parliament that was elected into office in 2010 has on many occasions been critical of the ongoing ceasefire efforts. Part of the reason for this criticism is that there was little communication between the MPC and Parliament and the latter felt slighted that it was not kept informed of an important and ongoing political effort. The formation of the Union Peace-making Central Committee helped to deflect some of these criticisms. Additionally, the task of the MPC often requires a good measure of confidentiality and quiet work in order to secure lasting arrangements. Given the sensitive nature of some of the dealings, it is not always possible to brief Parliament about all that transpires during meetings.

The MPC works closely with the Office of the President and, as mentioned earlier, the MPC's mandate and personnel are directly appointed by the President. Notwithstanding such strong credentials, the MPC is often subjected to criticisms in Parliament. In fact, there is some evidence to suggest that there has been a growing rift between the President on the one hand and Parliament on the other. Although some amount of separation of powers between the various arms of government is often viewed positively, especially in the parliamentary tradition where executive and legislative power is fused, the situation is sometimes 
dysfunctional in the Myanmar case.

A number of examples will suffice to illustrate this argument. For example, when the President wanted to declare Special Economic Zones to hasten the country's economic development, Parliament rejected it saying that such a declaration required parliamentary approval and was not an executive privilege (Eleven Newsmedia 2014a). Similarly, when four bills were presented to the President for safeguarding nationality and religion, in August 2013, the President dispatched these to the Parliament. However, the Parliament then turned over these documents to the different ministries for appraisal instead (Eleven Newsmedia 2014c). Given the sensitive nature of the bill that sought to entrench Buddhism and exclude and proscribe the activities of Bengalis and Muslims, the issue was clearly too sensitive to be dealt with publicly. And this development has to be considered in relation to the sporadic outbreaks of ethno-religious violence in Rakhine State, Lashio, and Mandalay and Yangon divisions. The MPC has also been tasked with attending to this sectarian violence and some of the members of the Rakhine Commission of Inquiry are drawn from the MPC. The Secretary of the Commission is Dr. Kyaw Yin Hlaing from the MPC and he is deeply involved in the investigation and recommendations of the Commission of Inquiry that was appointed by the President. ${ }^{4}$ Additionally, the MPC has been hosting interfaith dialogues in order to build much better rapport and tolerance between the Buddhist and Muslim communities in Rakhine State. Over time this process has also become regularized and is seen as one of the ways to engage the communities that are at odds with each other through elite dialogue and the dissemination of relevant information. The Rakhine Commission has also recommended significantly strengthening the enforcement capacity of the security agencies tasked with controlling violence (Republic of the Union of Myanmar 2013, 5053).

The military is another group that is not always satisfied with developments related to the peace process. Although both U Aung Min and President Thein Sein are from the military, operational commanders on the ground in conflict areas in Kachin and Shan states often have to make tactical decisions based on ground realities. And there have been occasions when the actions of the military appear to be in contradiction to executive orders. So, for example, President Thein Sein issued two executive orders in 2011 for the military to cease its offensive against the KIA but they came to no avail. Military commanders often complain that the troops are the ones that bear the brunt of armed action and therefore they have to retain some latitude to act in operational areas. Elements within the military are also known to doubt the peace process and remain unhappy about some of the assignments.

Finally, although the government has received much international support and good publicity for its ongoing work with the peace process, international donors and agencies often have their own agendas, and there are individuals keen 
to participate in and steer the peace process. So for example, some of the Western aid agencies have gender and environmental agendas. Similarly, at the ground level, some of these agencies are viewed with suspicion by the locals.

In the case of Rakhine State for example, the aid group Medecins sans Frontieres (MSF) had its operations in Rakhine State stopped. The ostensible reason for the stoppage was the general perception that the group was seen as being more sympathetic to the Bengali Muslim community than to the Rakhine Buddhist community. More recently, there was an outbreak of violence against international aid groups after a religious flag was brought down by a worker from the European aid group Malteser International (Irrawaddy 2014; Voice of America 2014). However, the government-appointed Sittwe Investigation Commission has since reported that the aid organization in question was not guilty of disrespecting the Buddhist flag and that its actions had been misinterpreted (Eleven Newsmedia 2014f). The situation on the ground is being complicated by a UN-sponsored census that could be viewed as political and used by different groups for their own purposes. In the case of Rakhine State, for example, the fear among the Rakhine Buddhists is that those currently classified as Bengali Muslim will agitate for the classification "Rohingya" that will then serve as a platform for the new group's gradual inclusion as one of the state-endorsed and recognized national ethnic groups.

\section{Conclusion}

Myanmar has certainly come a long way since the parliamentary elections of 2010. The country has made much progress in reconciling the often conflicting interests of many parties. With a history of ethnic insurgencies that has lasted for almost six decades, the country remains far from consolidated, even territorially and politically. In this regard the government does not exercise the sovereign powers that are often attendant on a national elected government. One of the most important issues that needs to be addressed in order for political reconciliation to succeed and for the country to progress is the resolution of the ethnic armed insurgency in the country. Whereas much progress has been made in this area since the first ceasefires were signed in 1988, there needs to be much more political consolidation of these efforts. The second issue that needs to be dealt with is the regular occurrence of ethno-religious conflict, especially that between Rakhine Buddhists and Bengali Muslims in Rakhine State. These sectarian and religious conflicts have each created approximately 140,000 internally displaced persons in Kachin and Rakhine states.

The Myanmar Peace Center that was inaugurated by the government in 2012 is an important part of the government's attempts to structurally and systematically address issues related to political violence. In this regard it is 
an important part of the government's infrastructure to secure lasting peace. Whereas the MPC has strong executive support within the country and has established a good international reputation, it is tasked with a difficult and unenviable job. It is still in the process of consolidating itself as a young organization and active facilitator of the peace process. It does suffer from a slew of challenges to its mandate and if it is not able to sew up the peace process (at least for the ethnic armed groups) by 2014, it stands being accused of incompetence. In the meantime, it is increasingly being tasked with new duties and many of these, like the land and squatter issues, are equally political. Also, despite its physical presence and gradual entrenchment, the MPC's leadership and mandate may be challenged after the 2015 national elections. In this regard, the MPC faces serious current and future obstacles.

\section{Notes}

The author would like to thank Dr. Kyaw Yin Hlaing and U Thihan Myo Nyun, the Director and Legal Counsel of the Myanmar Peace Center respectively, for the provision of valuable information for this article. They are however not responsible for the views contained in it.

1. The groups that had officially negotiated peace agreements with the government by 2004 were the Kachin Independence Organization (KIO), New Democratic Army (Kachin), Palaung State Liberation Organization, Myanmar National Democracy Alliance (MNDA - Kokang), Kachin Defense Army, Myanmar National Solidarity Party (Wa), National Democracy Alliance Army - Military Local Administration Committee (Shan/ Akhar), Shan State Army (SSA), Pa-O National Organization, Shan State Nationalities People's Organization, Mong Tai Army (MTA), Kayan National Guard, Kayinni National Progressive Party (KNPP), Kayan New Land Party, Kayinni National People's Liberation Front, and New Mon State Party (NMSP). The KNU, which concluded a first round of peace talks, had the ratification of the agreement delayed by the detention of head of Military Intelligence General Khin Nyunt, the architect of the agreements in 2004, and the death of its leader Saw Bo Mya in 2006. The agreement was eventually signed in 2012. The agreement with the KIO has broken down since June 2011 and there is no agreement yet with the Tauung/Palaung National Liberation Army (TNLA).

2. Under the 2008 Constitution, ministerial rank public officials who serve in Naypyitaw have to relinquish their parliamentary seats. These are then filled in a by-election.

3. The President of ME was and remains Tin Maung Than. He was previously Chairman of the Myanmar Fisheries Federation and rice cooperative. He was trained at the Asian Institute of Development in Thailand. The Internal Deputy Vice President is Hla Maung Shwe, who was detained and imprisoned for three years in the late 1980s for antigovernment activities. He was previously Chairman of the Shrimp Farmers Federation and currently is involved in private business. He is also the Deputy President of the United Myanmar Federation Chambers of Commerce and Industry (UMFCCI). Both of these leaders of ME have good linkages with the military. The latter's brother headed the Defence 
Science College in Naypyitaw and is now an ambassador. The External Vice President Sonny Nyunt Thein owns a travel agency and handled the logistics for ME. Dr. Nay Win Maung was the Secretary and despite being a medical doctor by training, he was involved in the publication of magazines that included The Voice. His father previously served in the military and he also had linkages to the military. The other board members are Dr. Kyaw Yin Hlaing, an academic, Kyaw Ni Khin, who is a developer and interior designer, and Ye Myat Thu, who runs his own information technology company in Mandalay. Dr. Nay Win Maung passed away suddenly after a heart attack in January 2012.

4. The MPC and Dr. Kyaw Yin Hlaing have been instrumental in the release of a number of official reports that document the ethno-religious violence in Rakhine State and other areas. Such publications include Final Report of Inquiry Commission on Sectarian Violence in Rakhine State (July 2013) and Report on the Outbreak of Sectarian Violence during September and October 2013 in Thandwe, Rakhine State (November 2013).

\section{References}

Chachavalpongpun, Pavin. 2005. A Pastic Nation: The Curse of Thainess in Thai-Burmese Relations. Lanham, MD: University Press of America.

ChannelnewsAsia. 2013. "EU Ends Myanmar Sanctions: Arms Embargo Remains.” April 22.

Eleven Newsmedia. 2014a. “Parliament Rejects President's Remark on Economic Zone Bill.” January 19.

Eleven Newsmedia. 2014b. "With New Pyidsaungsu Institute, a Second Peace Group Enters Talks." March 1.

Eleven Newsmedia. 2014c. "Different Opinions over Bills Safeguarding Nationality, Religion." March 2.

Eleven Newsmedia. 2014d. "NCCT Meeting to Be Held in Chiangmai." March 29.

Eleven Newsmedia. 2014e. "Government Officials and NCCT Members Meet at MPC." April 6.

Eleven Newsmedia. 2014f. "Commission Says NGO Staff Did Not Disrespect Buddhist Flag." April 11.

Eleven Newsmedia. 2014g. "Recent Clashes in Kachin Killed 8 Soldiers and 14 KIA Fighters." April 20.

Eleven Newsmedia. 2014h. "Why Conflict Continues in Kachin State." April 21.

Ganesan, N. 2005. "Myanmar's Foreign Policy.” In Myanmar: Beyond Politics to Societal Imperatives, eds. Yin Hlaing Kyaw, Robert H. Taylor, and Tin Maung Maung Than. Singapore: Institute of Southeast Asian Studies.

Ganesan, N., and Kyaw Yin Hlaing, eds. 2007. Myanmar: State, Society and Ethnicity. Singapore: Institute of Southeast Asian Studies.

Ganesan, N. 2010. "Myanmar's Relations with its Near Neighbours." International Studies Review 10 (1): 1-24.

Ganesan, N. 2013. "Interpreting Recent Developments in Myanmar as an Attempt to Establish Political Legitimacy." Asian Journal of Peacebuilding 1 (2): 253-274.

Haacke, Jurgen. 2006. Myanmar's Foreign Policy: Domestic Influences and International Implications. London: Routledge. 
Holliday, Ian. 2011. Burma Redux: Global Justice and the Quest for Political Reform in Myanmar. Hong Kong: Hong Kong University Press.

Kyaw, Yin Hlaing, Robert H. Taylor, and Tin Maung Maung Than, eds. 2005. Myanmar: Beyond Politics to Societal Imperatives. Singapore: Institute of Southeast Asian Studies.

Kyaw, Yin Hlaing. 2008. "Power and Factional Struggles in Post-Independence Myanmar Governments." Journal of Southeast Asian Studies 39 (1): 149-177.

Kyaw, Yin Hlaing. 2011. Political Impasse in Myanmar. City University of Hong Kong Working Paper Series No. 111. Hong Kong: City University of Hong Kong.

Kyaw, Yin Hlaing. 2012. “The Unexpected Arrival of a New Political Era in Myanmar." Unpublished manuscript.

Lehman, F. K., ed. 1981. Miltary Rule in Burma since 1962. Singapore: Maruzen Asia.

Maung, Aung Myoe. 2011. In the Name of Pauk Phaw: Myanmar's China Policy Since 1948. Singapore: Institute of Southeast Asian Studies.

Maung, Maung Gyi. 1981. "Foreign Policy of Burma since 1962: Negative Neutralism for Group Survival.” In Military Rule in Burma since 1962, ed. Frank K. Lehman. Singapore: Maruzen Asia.

Republic of the Union of Myanmar. 2013. "Final Report of Inquiry Commission on Sectarian Violence in Rakhine State." July 8.

Smith, Martin. 1991. Ethnicity and the Politics of Insurgency. London: Zed Books.

Smith, Martin. 1999. Ethnicity and the Politics of Insurgency. Second edition. London: Zed Books.

Steinberg, David. 2006. Turmoil in Burma: Contested Legitimacies. New York: Eastbridge.

Steinberg, David. 2007. "Legitimacy in Burma/Myanmar: Concepts and Implications." In Myanmar: State, Society and Ethnicity, eds. N. Ganesan and Kyaw Yin Hlaing. Singapore: Institute of Southeast Asian Studies.

Taylor, Robert H. 1987. The State in Burma. London: C. Hurst and Company.

Taylor, Robert H. 2007. "British Policy towards Myanmar and the Creation of the 'Burma problem.' In Myanmar: State, Society and Ethnicity, eds. N. Ganesan and Kyaw Yin Hlaing. Singapore: Institute of Southeast Asian Studies.

Taylor, Robert H. 2009. The State in Myanmar. Singapore: NUS Press.

Thawnghmung, Ardeth Maung. 2008. The Karen Revolution in Burma: Diverse Voices, Uncertain Ends. Honolulu: East-West Center.

Irrawaddy. 2014. "Arakanese Mob Attacks Aid Group Offices; Forces Staff to Flee." March 27.

The Research Team of the Inquiry Commission on Sectarian Violence in Rakhine State. 2013. Report on the Outbreak of Sectarian Violence in Rakhine State during September and October 2013 in Thandwe, Rakhine State, November. Rakhine: The Rakhine Inquiry Commission.

Tin, Maung Maung Than. 2007. State Dominance in Myanmar: The Political Economy of Industrialization. Singapore: Institute of Southeast Asian Studies.

Voice of America. 2014. "Buddhist Mob Attacks International Aid Group in Burma." March 27. 
N. Ganesan is Professor of Southeast Asian politics at the Hiroshima Peace Institute in Japan where he has been since 2004. His research and publication interests are in the sources of interstate and intrastate tensions in Southeast Asia. His most recent major works include State Violence in East Asia (Co-edited with Sung Chull Kim) (Lexington: University Press of Kentucky, 2013) and Conjunctures and Continuities in Southeast Asian Politics (Editor) (Singapore: Institute of Southeast Asian Studies, 2013). E-mail: ganesan@peace.hiroshima-cu.ac.jp 
